\title{
Comparison of folic acid content and chemical constituents from oyster mushrooms according to drying method and extraction conditions
}

\author{
Ki-Man Kim* \\ Department of Food Science and Technology, Gwangju University, Gwangju 61743, Korea
}

\section{건조방법 및 추출조건에 따른 느타리버섯의 엽산함량 및 화학성분 비교}

\author{
김기만* \\ 광주대학교 식품생명공학과
}

\begin{abstract}
This study aimed to acquire basic data about folic acid extracted from oyster mushrooms using hot water and ethanol under optimal conditions. We compared the chemical components and folic acid content in oyster mushrooms according to drying method and extraction conditions. The chemical components and the folic acid content did not significantly differ between lyophilized and cold air-dried oyster mushrooms (55.10 and $54.56 \mu \mathrm{g} \%$, respectively). However, the folic acid content significantly differed in hot air-dried oyster mushrooms $(53.83 \mu \mathrm{g} / 100 \mathrm{~g})$. The main free sugars in oyster mushrooms were fructose and glucose, and the major organic acids were citric acid and lactic acids. When measuring the yield and folic acid content with different solvent types and quantities, heating time, and temperatures, the optimal folic acid extraction conditions were addition of 20 -fold volumes of water to solid at $80^{\circ} \mathrm{C}$ for $8 \mathrm{~h}$, and 20-fold volumes of $50 \%$ ethanol to solid at $80^{\circ} \mathrm{C}$ for $8 \mathrm{~h}$, respectively. Chemical components did not significantly differ depending on extraction conditions, but more free sugars were extracted in hot water, and no differences were observed in organic acid contents. More folic acid was extracted when using hot water rather, than ethanol, probably because folic acid is water soluble.
\end{abstract}

Key words : folic acid, extraction, oyster mushrooms, general components, drying method

서 론

버섯은 분류학상으로 고등균류 중 진균류로 영양기관인 균사체와 번식기관인 포자를 지닌 자실체로 구분되며, 주로 산의 낙엽 밑, 마른 풀, 나뭇가지 등에 균사를 뻗어 영양을 섭취하면서 자라거나, 죽은 나무의 줄기 또는 뿌리에 기생하 여 자라는 것으로 알려져 있다(Kim 등, 2003; Yang 등, 1996). 우리나라에서 주로 재배되어 식용으로 이용되고 있는 느타리 버섯이 대표적이며, 느타리버섯은 육질이 연하고 다양한 필 수 아미노산 및 다양한 유기산과 지방산을 함유하고 있는 것
으로 보고되고 있고(Kim 등, 2004), 버섯의 이용이 증가하고 관심이 높아짐에 따라 버섯에 대한 유효성분 및 효능에 대한 다양한 연구가 이루어지고 있다. 버섯의 효과는 항산화 및 항 암작용(Park 등, 1998) 당뇨병, 심혈관질환, 콜레스테롤 저해 능, 항산화 효과 등 여러 약리효과를 가진다(Kim과 Kang, 2012; Park과 Kim, 2013). 그밖에 느타리버섯, 양송이버섯, 팽이버섯의 물질 함량 분석(Kim 등, 2010), 새송이버섯의 항 염증 활성(Kim 등, 2005), 식용 및 약용버섯의 항산화 및 항 암효과 등의 연구가 보고되었다(Jing과 Kitts, 2004; Qi 등, 2013).

*Corresponding author. E-mail : kmkim@gwangju.ac.kr, Phone : +82-62-670-2444, Fax : +82-62-670-2444

Received 17 July 2020; Revised 14 August 2020; Accepted 04 September 2020.

Copyright (c) The Korean Society of Food Preservation.

This is an Open Access article distributed under the terms of the Creative Commons Attribution Non-Commercial License (http://creativecommons.org/licenses/by-nc/4.0) which permits unrestricted non-commercial use, distribution, and reproduction in any medium, provided the original work is properly cited. 
많은 현대인들이 건강한 식재료에 관심을 가지면서 식용 및 약용이 모두 가능한 버섯에 대한 수요가 증가함에 따라, 현재 대부분의 버섯은 자연 채취로 공급하기 어려워 인공적 인 방법으로 재배되고 있으며, 버섯의 일반성분 중 조단백질 은 $30.20 \%$, 조지방은 $1.80 \%$, 회분은 $5.16 \%$, 총 당은 $43.50 \%$, 환원당은 $2.56 \%$ 등이며, 이러한 버섯은 일반 식재료로 이용 될 뿐만 아니라, 건강기능식품, 화장품, 의약품 등 다양한 분 야의 원료 물질로 이용되고 있다고 보고되고 있다(Gropper 등, 2005; Hong 등, 1988; Kim 등, 2004).

본 연구의 대상인 느타리버섯(oyster mushroom) 성분으 로 lactic acid, oxalic acid, fumaric acid, succinic acid, malic acid, citric acid, pyroglutamic acid 등의 유기산과 지방산, trehalose, glucose, fructose, mannitol, arabitol, glycerol 등의 유리당 및 당알코올류의 다양한 성분 연구 및 폴리페놀 화합 류의 항산화능에 대해 보고되었다(Barrosa 등, 2007; Hossain 등, 2003; Jung 등, 1996). 또한, 느타리버섯이 다량 함유하고 있는 엽산(folic acid)은 비타민 B 복합체 중 하나로, 자연계 에 널리 분포하며, 특히 과일류, 채소류, 콩류, 동물의 간에 많이 함유되어 있다. 엽산은 체내에서 세포 분열 및 생장에 필요한 핵산, 아미노산 등을 합성하는데 필수적이며, 비타민 $\mathrm{B}_{12}$ 와 결합해 성장 발달과 적혈구 생산에 이용되고, 뇌의 신 경전달물질인 노르아드레날린의 분비를 촉진할 뿐만 아니 라, 혈관을 이완시켜 고혈압의 위험을 낮추는데 기여한다 (Arcot과 Shrestha, 2005; Chang 등, 1993; Kang과 Chang, 1993).

이러한 엽산은 영유아식이나 건강기능식품 등의 식품을 가공하는데 부족한 영양소를 보충하기 위해 첨가되는 식품첨 가물, 건강 증진이나 영양 결핍 예방을 위해 섭취되는 영양제 등 여러 용도로 사용된다. 그러나, 제품의 생산 비용을 절감 하기 위해 주로 화학적으로 합성된 형태의 엽산을 이용하였 는데, 최근에는 건강에 관심 있는 소비자가 늘어나면서 화학 적 합성보다는 천연 재료에서 추출된 물질에 대한 선호도가 늘어나는 추세이다(Blom과 Smulders, 2011; Green, 2011; Gropper 등, 2005; Hong 등, 1988).

따라서 본 연구에서는 시장의 흐름에 맞춰 느타리버섯으 로부터 엽산을 추출하기 위한 다양한 방법을 모색하였고, 또한 산업적으로 활용할 수 있는 기초자료를 제공하고자 하 였다.

\section{재료 및 방법}

\section{재료 및 시약}

본 실험에 사용한 느타리버섯 자실체는 2019년 1월에 전 남 장흥군 (주)기뽐농원에서 구입하여 사용하였으며, $-20^{\circ} \mathrm{C}$ 에
서 냉동 보관하면서 시료로 사용하였으며, 본 실험에 사용한 folic acid 표준품, protease, $\alpha$-amylase는 Sigma-Aldrich(St. Louis, $\mathrm{MO}, \mathrm{USA})$ 에서 구입하였으며, 엽산 분석에 사용된 Lactobacillus casei(KCCM 12452), Lactobacillus rhamnosus (KCCM 32405)는 한국미생물보존센터에서 구입하였으며, 배양 배지로 사용된 Bacto agar, Lactobacilus MRS broth는 $\mathrm{Difco}$ 사 제품을 사용하였으며 냉장보관하며 사용하였다. 증 류수는 (Milli-Q A10 Reference, Millipore Co., USA) 으로 정 제하여 사용하였으며, 기타 사용된 시약은 Sigma- Aldrich 사 에서 구입하여 사용하였다.

\section{건조방법}

본 실험에 사용할 느타리버섯 건조는 총 3 가지 건조방법을 이용하여 건조하였다. 열풍건조는 열풍건조기(SIN-1500, Sinil Co., Gwangju, Korea)를 사용하여 $80^{\circ} \mathrm{C}$ 에서 12 시간 건조하였 고, 냉풍건조는 냉풍건조기(SI-101, Insin Co., Dongducheon, Korea)를 사용하여 $10^{\circ} \mathrm{C} 12$ 시간 건조하였다. 또한, 동결건조 는 동결건조기(LP50 series, Insin Co.)를 사용하여 $-40^{\circ} \mathrm{C}$ 에서 48시간 동안 동결건조하였다. 건조물의 최종 수분함량은 $10 \%$ 이하로 건조하였다.

\section{열수 및 에탄올 추출}

느타리버섯의 추출물 제조는 열수추출(hot water extraction; $\mathrm{HE})$, 에탄올추출(ethanol extraction; $\mathrm{EE}$ ) 방법으로 추출하였 다. 최적의 추출조건을 및 추출표준화 조건을 설정하고자 열 수와 주정추출 모두 환류추출기를 이용하여(CA-112, Eyela Co., Tokyo, Japan) $100 \mathrm{~g}$ 의 느타리버섯 자실체 건조물에 각 각 $1.5 \mathrm{~L}, 2.0 \mathrm{~L}, 2.5 \mathrm{~L}, 3.0 \mathrm{~L}$ 를 첨가하여 추출하였고, 추출온 도는 $60^{\circ} \mathrm{C}, 70^{\circ} \mathrm{C}, 80^{\circ} \mathrm{C}, 90^{\circ} \mathrm{C}$, 추출시간은 4 시간, 5 시간, 6 시 간, 7 시간, 8 시간 각각 추출하여 최적의 열수 추출조건을 설 정하고자 하였다. 에탄올 추출의 경우, 물 추출물과는 다르게 에탄올 함량을 $30 \%, 40 \%, 50 \%, 60 \%$ 로 조정하여 에탄올 함 량에 따른 차이도 비교해 보고자 하였다. 각각의 추출물은 여 과지(Whatman paper No.2)를 이용하여 여과시켰다. 여액은 농축기(N-1000S-W, Tokyo Rikakikai Co., Tokyo, Japan)를 사용하여 감압농축한 뒤, 동결건조(PVTFD10R, Ilshin lab Co., Dongducheon, Korea)하여 $-40^{\circ} \mathrm{C}$ 이하의 냉동고에 보관 하면서 분석용 시료로 사용하였다.

\section{일반성분 분석}

본 연구에 사용한 느타리버섯 및 건조방법별 느타리버섯 의 일반성분 분석은 $\mathrm{AOAC}$ 방법(AOAC, 1997)에 따라 수행 하였다. 수분함량은 $105^{\circ} \mathrm{C}$ 상압 건조 후 항량을 측정하여 산 출하였고, 조단백질은 micro-Kjeldahl법, 조지방은 Soxhlet 
추출장치로 추출하여 측정하였으며, 조회분은 $550^{\circ} \mathrm{C}$ 직접회 화법으로 3 회 반복하여 측정하였으며, 탄수화물 함량은 전체 $100 \%$ 으로 하여 수분, 조단백질, 조지방과 조회분 함량을 제 외한 값을 탄수화물 함량(\%)으로 하였다.

\section{엽산 분석}

Trienzyme 추출법에 의한 엽산분석을 시행하였다. 삼각플 라스크에 분석 시료 약 $5 \mathrm{~g}$ 과 $0.1 \mathrm{M}$ phosphate buffer $(\mathrm{pH} 7.8$, $1 \%$ ascorbic acid) 및 증류수를 각각 가하고 $100^{\circ} \mathrm{C}$ 에서 15 분 간 열처리 및 냉각하였다. 사용 전 바로 제조한 protease 용액 $(2 \mathrm{mg} / \mathrm{mL}) 1 \mathrm{~mL}$ 를 가하여 $37^{\circ} \mathrm{C}$ 에서 3 시간 반응시키고 $100^{\circ} \mathrm{C}$ 에서 5 분간 열처리하여 protease를 불활성화시켰다. 동일 플 라스크에 $\alpha$-amylase 용액 $(20 \mathrm{mg} / \mathrm{mL}) 1 \mathrm{~mL}$ 를 넣고 $37^{\circ} \mathrm{C}$ 에서 2시간 반응을 진행한 뒤 conjugase 용액 $(5 \mathrm{mg} / \mathrm{mL}) 4 \mathrm{~mL}$ 를 가하여 16 시간 가수분해하였다. 효소반응을 정지시키기 위해 $100^{\circ} \mathrm{C}$ 에서 5 분간 열처리하고 추출액의 $\mathrm{pH}$ 를 4.5 로 조정한 뒤 $100 \mathrm{~mL}$ 로 정용하여 정량 시료로 사용하였다. 추출물의 엽산 정량은 Lactobacillus casei(KCCM 12452), Lactobacillus rhamnosus(KCCM 32405)를 이용한 미생물학적 방법에 의해 실시하였다(Kim 등, 1998).

\section{유리당 분석}

유리당 함량은 DeVries 등(2005)의 방법에 준하여 분석하 였다. 즉, 시료 $5 \mathrm{~g}$ 에 증류수를 가하여 교반시킨 후 $100 \mathrm{~mL}$ 로 정용하여 원심분리 $(50,000 \mathrm{rpm}, 30 \mathrm{~min})$ 하고 상징액을 취하 여 여과(Whatman No.2)하였다. 여과한 여액을 Sep-pak $\mathrm{C}_{18}$ 으로 정제시킨 후, $0.45 \mu \mathrm{m}$ membrane filter(Millipore Co., USA)로 여과 후 HPLC system(1200 series, Agilent, Palo Alto, CA, USA)을 이용하여 수행하였으며, 검출기는 $\mathrm{ELSD}$ (1200 series, Agilent, Les Ulis, France), column은 carbohydrate column $(250 \times 4.6 \mathrm{~mm}$, Agilent, Richardson, TX, USA) 을 사용하였고, 이동상은 $75 \%$ acetonitrile을 사용하였다. 유 속은 분당 $1.0 \mathrm{~mL}$ 였으며, 시료 주입량은 $10 \mu \mathrm{L}$ 로 하여 실험 을 진행하였다.

\section{유기산 분석}

유기산 함량은 유리당의 방법과 동일하게 처리 후 HPLC system(Agilent, USA)을 이용하여 분석하였으며, column은 organic acid column $(250 \times 4.6 \mathrm{~mm}$, Alltech Co., Deerfield, IL, USA)을 사용하였고, 이동상은 $25 \mathrm{mM} \mathrm{NaHPO}$ 를 사용하였 다. 유속은 분당 $1.0 \mathrm{~mL}$ 였으며, 검출 파장은 $210 \mathrm{~nm}$, 시료 주입량은 $10 \mu \mathrm{L}$ 로 하여 실험을 진행하였다.

\section{통계처리}

모든 실험은 3 회 반복하였으며, 실험결과를 SPSS 통계프 로그램(ver. 17.0, SPSS Inc., USA) 을 이용하여 평균값과 표 준편차를 산출하였고, Duncan's multiple range test를 통해 유의성 $(\mathrm{p}<0.05)$ 을 검증하였다.

\section{결과 및 고찰}

\section{일반성분}

본 실험에 사용한 느타리버섯의 일반성분 함량은 Table 1 과 같다. 느타리버섯의 일반성분은 수분 $87.11 \pm 0.50 \%$, 조단 백 $2.24 \pm 0.14 \%$, 조지방 $0.77 \pm 0.06 \%$, 조회분 $0.43 \pm 0.04 \%$, 탄 수화물 9.45 \pm 0.02 의 결과를 보였다. Lee 등(2018)에 따르면 느타리버섯의 일반성분의 경우 수분 $89.5 \%-93.1 \%$, 조단백 $2.9 \%-2.8 \%$, 조지방 $0.1 \%-0.3 \%$, 조회분 $0.5 \%-0.9 \%$ 로 보고하 였는데, 실험결과 이와 유사한 결과를 나타내었다.

\section{건조방법에 따른 일반성분 및 엽산 함량}

느타리버섯의 건조방법에 따른 일반성분 및 엽산함량 변 화를 측정한 결과는 Table 2 와 같다. 수분함량은 열풍건조 $9.19 \%$, 냉풍건조 $9.36 \%$, 동결건조 $9.12 \%$ 로 유의적인 차이를 보이지 않고 수분함량 $10 \%$ 내외로 잘 건조되는 것을 확인하 였고, 수분, 조단백, 조지방, 조회분 및 carbohydrate 등의 성 분도 건조방법에 따른 유의적인 차이가 없었다.

엽산함량은 동결건조로 건조한 느타리버섯에서 $55.10 \mu \mathrm{g} / 100$ $\mathrm{g}$ 으로 냉풍건조 느타리버섯 $54.56 \mu \mathrm{g} / 100 \mathrm{~g}$ 과 비교하여 유의 적인 차이를 보이지 않았으나, 열풍건조 느타리버섯 $53.83 \mu \mathrm{g} / 100$ $\mathrm{g}$ 과는 유의적인 차이가 있었다. Park 등(2017)에 따르면 느타 리버섯을 열처리하여 조리하게 되면 엽산함량이 $17-56 \%$ 감 소한다고 보고하였으며, $\operatorname{Min}(1998)$ 은 시금치를 열처리하여 조리 시 엽산함량이 $19.3 \%$ 감소한다고 보고하였는데, 이와 유사한 결과를 보였다. 이는 열풍으로 건조하는 동안 느타리 버섯이 고온에 장시간 노출되면서 엽산함량이 약간 감소된

Table 1. Proximate composition of oyster mushrooms

\begin{tabular}{cccccc}
\hline & Moisture & Crude protein & Crude lipid & Crude ash & Carbohydrate \\
\hline Composition & $87.11 \pm 0.50^{1)}$ & $2.24 \pm 0.14$ & $0.77 \pm 0.06$ & $0.43 \pm 0.04$ & $9.45 \pm 0.02$ \\
\hline
\end{tabular}

${ }^{1)}$ Each value represents the mean $\pm \mathrm{SD}$ of three determinations. 
Table 2. Proximate composition of oyster mushrooms by different drying methods

\begin{tabular}{ccccccc}
\hline Drying method & $\begin{array}{c}\text { Moisture } \\
(\%)\end{array}$ & $\begin{array}{c}\text { Crude protein } \\
(\%)\end{array}$ & $\begin{array}{c}\text { Crude lipid } \\
(\%)\end{array}$ & $\begin{array}{c}\text { Crude ash } \\
(\%)\end{array}$ & $\begin{array}{c}\text { Carbohydrate } \\
(\%)\end{array}$ & $\begin{array}{c}\text { Folic acid content } \\
(\mu \mathrm{g} / 100 \mathrm{~g})\end{array}$ \\
\hline Hot-air dried & $9.19 \pm 0.13^{1) \mathrm{ab} 2)}$ & $2.45 \pm 0.09$ & $0.76 \pm 0.04$ & $0.41 \pm 0.02$ & $87.19 \pm 0.03$ & $53.83 \pm 0.20^{\mathrm{c}}$ \\
Cold-air dried & $9.36 \pm 0.72^{\mathrm{a}}$ & $2.43 \pm 0.07$ & $0.77 \pm 0.03$ & $0.39 \pm 0.02$ & $87.05 \pm 0.05$ & $54.56 \pm 0.66^{\mathrm{ab}}$ \\
Freeze-dried & $9.12 \pm 0.08^{\mathrm{b}}$ & $2.45 \pm 0.55$ & $0.75 \pm 0.04$ & $0.38 \pm 0.01$ & $87.30 \pm 0.01$ & $55.10 \pm 0.34^{\mathrm{a}}$ \\
\hline
\end{tabular}

${ }^{1)}$ Each value represents the mean $\pm \mathrm{SD}$ of three determinations.

${ }^{2}$ Mean with different superscripts $\left({ }^{\mathrm{a}-\mathrm{c}}\right)$ are significantly different at $\mathrm{p}<0.05$ by Duncan's multiple range test.

것으로 사료된다.

\section{건조방법에 따른 유리당 함량}

느타리버섯의 건조 방법에 따른 유리당 함량을 측정한 결 과는 Table 3과 같다. Fructose, glucose, lactose, maltose 4가 지 유리당이 검출되었으며, 주요 유리당은 fructose와 glucose 로 나타났다. 건조방법 glucose 함량은 동결건조한 느타리버 섯이 $2.448 \pm 56.82 \mathrm{mg} \%$ 로 가장 높았으며 열풍건조 $2,361 \pm 68.46$ $\mathrm{mg} \%$, 냉풍건조 $2,309 \pm 36.47 \mathrm{mg} \%$ 순으로 높게 나타났다. 다 음으로 fructose 함량이 높게 나타났다. Fructose는 열풍건조 한 느타리버섯이 $1,499 \pm 50.16 \mathrm{mg} \%$, 냉풍건조 $1,434 \pm 17.21$ $\mathrm{mg} \%$, 동결건조 $1,342 \pm 53.02 \mathrm{mg} \%$ 순으로 높게 나타났다. 느 타리버섯의 총 유리당은 열풍건조한 느타리버섯이 $5,388 \pm 48.11$ $\mathrm{mg} \%$, 냉풍건조한 느타리버섯이 $5,163 \pm 27.54 \mathrm{mg} \%$, 동결건 조한 느타리버섯이 $4,269 \pm 59.22 \mathrm{mg} \%$ 함량을 보여 열풍건조 로 건조한 느타리버섯의 유리당 함량이 가장 높게 나타났다. 식물에 많이 함유되어 있는 유리당은 항염증, 항산화 등과 관 련되는 것으로 알려져 있으며(Qi 등, 2013), Kim 등(2004)에 따르면 느타리버섯의 자실체에 대한 유리당 함량은 glucose 가 $2,040 \mathrm{mg} \%$ 로 가장 많고, fructose, ribose, maltose 순으로 낮은 함량을 보였다고 보고하였는데, 이와 비슷한 결과를 나 타내었다. Je 등(2018)은 건조방법별 버섯의 품질특성을 비교 하였는데, 일반성분을 포함한 다양한 성분이 버섯의 이화학 적 특성에 따라 달라진다고 하였고, 새송이버섯은 동결건조, 이슬송이버섯은 $30^{\circ} \mathrm{C}$ 진공저온건조, 잎새버섯은 $50^{\circ} \mathrm{C}$ 열풍건
조가 품질특성이 좋아진다고 보고하였다. 본 연구결과, 느타 리버섯의 유리당 함량은 열풍건조를 사용해서 건조한 버섯이 가장 높게 나타나 이는 느타리버섯의 품질특성 때문일 것으 로 사료된다.

\section{건조방법에 따른 유기산 함량}

느타리버섯의 건조 방법에 따른 유기산 함량을 측정한 결 과는 Table 4와 같다. Citric acid malic acid, acetic acid, succinic acid 및 lactic acid 총 5종이 검출되었으며, citric acid와 lactic acid 의 함량이 모든 시료구에서 높게 나타났다. 건조방법별 유기산 함량은 열풍건조한 느타리버섯이 가장 높 았으며, citric acid $25.16 \pm 0.40 \mathrm{mg} \%$, malic acid $10.46 \pm 0.30$ $\mathrm{mg} \%$, acetic acid $10.43 \pm 0.45 \mathrm{mg} \%$, succinic acid $4.16 \pm 0.30$ $\mathrm{mg} \%$ 및 lactic acid $25.00 \pm 0.45 \mathrm{mg} \%$ 로 나타났으며 총 유기산 함량은 $75.21 \pm 0.39 \mathrm{mg} \%$ 동결건조한 느타리버섯, $74.42 \pm 0.24$ $\mathrm{mg} \%$ 냉풍 건조한 느타리버섯 $71.69 \pm 0.24 \mathrm{mg} \%$ 순으로 높은 함량을 보였다. Kim 등(2004)에 따르면 느타리버섯의 유기산 함량은 7종이 확인되었다고 보고하였으며, citric acid가 가장 높은 함량을 나타내고 oxalic acid, formic acid, malic acid, succinic acid 순으로 함유되어 있다고 보고하였고, Hong 등 (1988)에 따르면 표고, 양송이, 느타리버섯의 유기산 함량을 분석한 결과, malic acid, citric acid가 많이 함유하고 있다고 보고하여 이와 비슷한 결과를 나타내었다.

\section{엽산 추출을 위한 최적 열수추출조건}

Table 3. Free sugar of oyster mushrooms with different drying methods

\begin{tabular}{cccccc}
\hline \multirow{2}{*}{ Drying method } & \multicolumn{5}{c}{ Free sugar $(\mathrm{mg} \%)$} \\
\cline { 2 - 6 } & Glucose & Fructose & Lactose & Maltose & Total \\
\hline Hot-air dried & $2,361 \pm 68.46^{1) \mathrm{ab} 2)}$ & $1,499 \pm 50.16^{\mathrm{a}}$ & $978 \pm 18.75^{\mathrm{a}}$ & $550 \pm 24.98^{\mathrm{a}}$ & $5,388 \pm 48.11^{\mathrm{a}}$ \\
Cold-air dried & $2,309 \pm 36.47^{\mathrm{b}}$ & $1,434 \pm 17.21^{\mathrm{a}}$ & $861 \pm 25.01^{\mathrm{b}}$ & $559 \pm 24.94^{\mathrm{a}}$ & $5,163 \pm 27.54^{\mathrm{a}}$ \\
Freeze-dried & $2,448 \pm 56.82^{\mathrm{a}}$ & $1,342 \pm 53.02^{\mathrm{b}}$ & $762 \pm 95.91^{\mathrm{c}}$ & $479 \pm 21.93^{\mathrm{b}}$ & $4,269 \pm 59.22^{\mathrm{b}}$ \\
\hline
\end{tabular}

${ }^{1)}$ Each value represents the mean \pm SD of three determinations.

${ }^{2)}$ Mean with different superscripts $\left({ }^{\mathrm{a}-\mathrm{c}}\right)$ are significantly different at $\mathrm{p}<0.05$ by Duncan's multiple range test. 
Table 4. Organic acids of oyster mushrooms with different drying methods

\begin{tabular}{ccccccc}
\hline \multirow{2}{*}{ Drying method } & \multicolumn{5}{c}{ Organic acid $(\mathrm{mg} \%)$} \\
\cline { 2 - 7 } & Citric acid & Malic acid & Acetic acid & Succinic acid & Lactic acid & Total \\
\hline Hot-air dried & $\left.25.16 \pm 0.40^{1) \mathrm{a} 2}\right)$ & $10.46 \pm 0.30^{\mathrm{a}}$ & $10.43 \pm 0.45^{\mathrm{a}}$ & $4.16 \pm 0.30^{\mathrm{b}}$ & $25.00 \pm 0.45^{\mathrm{ab}}$ & $75.21 \pm 0.39^{\mathrm{a}}$ \\
Cold-air dried & $23.50 \pm 0.60^{\mathrm{b}}$ & $10.33 \pm 0.20^{\mathrm{a}}$ & $9.33 \pm 0.20^{\mathrm{b}}$ & $4.33 \pm 0.20^{\mathrm{b}}$ & $24.20 \pm 0.26^{\mathrm{b}}$ & $71.69 \pm 0.24^{\mathrm{b}}$ \\
Freeze-dried & $25.03 \pm 0.50^{\mathrm{a}}$ & $9.37 \pm 0.15^{\mathrm{b}}$ & $9.33 \pm 0.15^{\mathrm{b}}$ & $5.46 \pm 0.05^{\mathrm{a}}$ & $25.23 \pm 0.15^{\mathrm{a}}$ & $74.42 \pm 0.24^{\mathrm{a}}$ \\
\hline
\end{tabular}

${ }^{1)}$ Each value represents the mean \pm SD of three determinations.

${ }^{2)}$ Mean with different superscripts $\left({ }^{\mathrm{a}, \mathrm{b}}\right)$ are significantly different at $\mathrm{p}<0.05$ by Duncan's multiple range test.

최적의 엽산추출을 위한 느타리버섯 최적 추출조건 설정 을 위해 추출조건을 표준화 하고자 가열온도, 가열시간, 용매 첨가량 변화에 따라 등 고형분, 이론수율, 엽산함량을 측정한 결과는 Table 5-7과 같다.

열수를 이용한 느타리버섯 최적 추출조건 설정을 위하여 첫 번째, 용매량에 따른 느타리버섯의 추출 수율을 확인하였 다. 추출 수율은 각각의 추출액을 동결건조시켜서 건물 중량 을 구한 다음 추출액 조제에 사용한 원료 건물량에 대한 백분 율로 나타내었으며, 용매량은 원물 $1 \mathrm{~kg}$ 에 물을 각각 $15 \mathrm{~L}$,
$20 \mathrm{~L}, 25 \mathrm{~L}$ 및 $30 \mathrm{~L}$ 를 첨가하고, $90^{\circ} \mathrm{C}$ 에서 8 시간 가열하여 추출한 결과, 고형분 함량은 용매량 15 배수로 추출한 시료구 에서 $2.76 \%$ 로 가장 높은 함량을 나타내었고, $20,25,30$ 배수 순으로 낮은 함량을 보였다. 최종수율은 추출물을 분말화하 였을 때 얻을 수 있는 양을 최종량과 고형분함량 비율로 계산 하였고, 그 결과는 용매량 20 배수를 첨가한 시료구에서 2.62 $\mathrm{g}$ 으로 가장 높은 함량을 보였으며, 엽산함량 역시 20배수 용 매량을 첨가한 시료구에서 $56.30 \mu \mathrm{g} / 100 \mathrm{~g}$ 으로 가장 높은 함 량을 보여 느타리버섯의 최적추출에 적합한 용매량은 20 배

Table 5. Extraction efficiency and folic acid content of oyster mushrooms according to hot water volume amount

\begin{tabular}{|c|c|c|c|c|c|c|}
\hline \multicolumn{3}{|c|}{ Extraction condition } & \multicolumn{4}{|c|}{ Extraction solution } \\
\hline $\begin{array}{l}\text { Solvent } \\
\text { volume } \\
\text { (L) }\end{array}$ & $\begin{array}{l}\text { Extraction } \\
\text { time } \\
\text { (h) }\end{array}$ & $\begin{array}{c}\text { Extraction } \\
\text { temperature } \\
(\mathrm{C})\end{array}$ & $\begin{array}{l}\text { Final quantity } \\
\text { (L) }\end{array}$ & $\begin{array}{l}\text { Solid content } \\
\quad\left({ }^{\circ} \text { Brix }\right)\end{array}$ & $\begin{array}{l}\text { Yield } \\
(\mathrm{g})\end{array}$ & $\begin{array}{l}\text { Folic acid content } \\
\qquad(\mu \mathrm{g} / 100 \mathrm{~g})\end{array}$ \\
\hline 15 & 8 & 90 & 6.7 & $2.76 \pm 0.05^{1) \mathrm{a} 2)}$ & $1.86 \pm 0.01^{\mathrm{d}}$ & $51.00 \pm 1.44^{\mathrm{ab}}$ \\
\hline 20 & 8 & 90 & 12.4 & $2.03 \pm 0.05^{\mathrm{b}}$ & $2.62 \pm 0.03^{\mathrm{a}}$ & $56.30 \pm 1.05^{\mathrm{a}}$ \\
\hline 25 & 8 & 90 & 16.7 & $1.36 \pm 0.05^{\mathrm{c}}$ & $2.32 \pm 0.01^{\mathrm{c}}$ & $53.20 \pm 0.80^{\mathrm{b}}$ \\
\hline 30 & 8 & 90 & 21.5 & $1.06 \pm 0.05^{\mathrm{d}}$ & $2.47 \pm 0.09^{b}$ & $50.93 \pm 0.64^{\mathrm{ab}}$ \\
\hline
\end{tabular}

${ }^{1)}$ Each value represents the mean $\pm \mathrm{SD}$ of three determinations.

${ }^{2}$ Mean with different superscripts $\left({ }^{\mathrm{a}-\mathrm{d}}\right)$ are significantly different at $\mathrm{p}<0.05$ by Duncan's multiple range test.

Table 6. Extraction efficiency and folic acid content according to extraction temperature with hot water

\begin{tabular}{|c|c|c|c|c|c|c|}
\hline \multicolumn{3}{|c|}{ Extraction condition } & \multicolumn{4}{|c|}{ Extraction solution } \\
\hline $\begin{array}{l}\text { Solvent } \\
\text { volume } \\
\text { (L) }\end{array}$ & $\begin{array}{l}\text { Extraction } \\
\text { time } \\
\text { (h) }\end{array}$ & $\begin{array}{c}\text { Extraction } \\
\text { temperature } \\
(\mathrm{C})\end{array}$ & $\begin{array}{l}\text { Final quantity } \\
\text { (L) }\end{array}$ & $\begin{array}{l}\text { Solid content } \\
\quad\left({ }^{\circ} \text { Brix }\right)\end{array}$ & $\begin{array}{l}\text { Yield } \\
(\mathrm{g})\end{array}$ & $\begin{array}{l}\text { Folic acid content } \\
\qquad(\mu \mathrm{g} / 100 \mathrm{~g})\end{array}$ \\
\hline 20 & 8 & 60 & 12.5 & $2.17 \pm 0.20^{1) \mathrm{ab} 2)}$ & $2.48 \pm 0.03^{\mathrm{b}}$ & $52.20 \pm 1.00^{\mathrm{b}}$ \\
\hline 20 & 8 & 70 & 12.5 & $2.07 \pm 0.05^{\mathrm{b}}$ & $2.72 \pm 0.08^{\mathrm{a}}$ & $50.84 \pm 0.49^{\mathrm{b}}$ \\
\hline 20 & 8 & 80 & 12.5 & $2.33 \pm 0.05^{\mathrm{a}}$ & $2.82 \pm 0.06^{\mathrm{a}}$ & $54.61 \pm 0.75^{\mathrm{a}}$ \\
\hline 20 & 8 & 90 & 12.5 & $2.37 \pm 0.05^{\mathrm{a}}$ & $2.56 \pm 0.05^{\mathrm{b}}$ & $57.92 \pm 0.91^{\mathrm{a}}$ \\
\hline
\end{tabular}

${ }^{1)}$ Each value represents the mean \pm SD of three determinations.

${ }^{2)}$ Mean with different superscripts $\left({ }^{\mathrm{a}, \mathrm{b}}\right)$ are significantly different at $\mathrm{p}<0.05$ by Duncan's multiple range test. 
Table 7. Extraction efficiency and folic acid content according to extraction time with hot water

\begin{tabular}{|c|c|c|c|c|c|c|}
\hline \multicolumn{3}{|c|}{ Extraction condition } & \multicolumn{4}{|c|}{ Extraction efficiency } \\
\hline $\begin{array}{l}\text { Solvent } \\
\text { volume } \\
\text { (L) }\end{array}$ & $\begin{array}{l}\text { Extraction } \\
\text { time } \\
\text { (h) }\end{array}$ & $\begin{array}{l}\text { Extraction } \\
\text { temperature } \\
\left({ }^{\circ} \mathrm{C}\right)\end{array}$ & $\begin{array}{l}\text { Final quantity } \\
\text { (L) }\end{array}$ & $\begin{array}{l}\text { Solid content } \\
\quad\left({ }^{\circ} \text { Brix }\right)\end{array}$ & $\begin{array}{l}\text { Yield } \\
(\mathrm{g})\end{array}$ & $\begin{array}{l}\text { Folic acid content } \\
\qquad(\mu \mathrm{g} / 100 \mathrm{~g})\end{array}$ \\
\hline 20 & 2 & 80 & 12.5 & $1.56 \pm 0.11^{1) \mathrm{c} 2}$ & $1.49 \pm 0.05^{\mathrm{c}}$ & $50.50 \pm 0.90^{\mathrm{b}}$ \\
\hline 20 & 4 & 80 & 12.5 & $1.63 \pm 0.20^{\mathrm{c}}$ & $2.37 \pm 0.20^{\mathrm{b}}$ & $50.98 \pm 0.42^{\mathrm{b}}$ \\
\hline 20 & 6 & 80 & 12.5 & $1.95 \pm 0.05^{\mathrm{b}}$ & $2.47 \pm 0.05^{\mathrm{ab}}$ & $53.70 \pm 0.95^{\mathrm{ab}}$ \\
\hline 20 & 8 & 80 & 12.5 & $2.30 \pm 0.43^{\mathrm{a}}$ & $2.63 \pm 0.04^{\mathrm{a}}$ & $55.75 \pm 0.82^{\mathrm{a}}$ \\
\hline
\end{tabular}

${ }^{1)}$ Each value represents the mean $\pm \mathrm{SD}$ of three determinations.

${ }^{2}$ Mean with different superscripts ${ }^{(\mathrm{a}-\mathrm{c}}$ ) are significantly different at $\mathrm{p}<0.05$ by Duncan's multiple range test.

로 확인되었다.

온도변화에 따른 추출수율을 확인하고자 용매량을 20 배 수, 추출시간을 8 시간으로 고정하고, 추출온도를 $60^{\circ} \mathrm{C}, 70^{\circ} \mathrm{C}$, $80^{\circ} \mathrm{C}$ 및 $90^{\circ} \mathrm{C}$ 로 추출한 뒤 느타리버섯의 추출효율 및 엽산함 량 변화를 측정하였다. 그 결과, 고형분은 $80^{\circ} \mathrm{C}$ 에서 추출한 시료구에서 $2.33 \%$ 로 가장 높게 나타났으며, 고형분 함량도 $2.82 \mathrm{~g}$ 으로 가장 높았다. 엽산함량 또한 $54.61 \mu \mathrm{g} \%$ 으로 가장 높은 함량을 보여 느타리버섯 추출에 가장 적합한 온도는 $80^{\circ} \mathrm{C}$ 로 확인되었다.

추출시간 변화에 따른 느타리버섯 추출효율 및 엽산함량 변화를 측정하기 위하여 용매량과 가열시간을 고정한 뒤, 가 열시간 변화에 따른 고형분과 이론 수율 엽산함량을 측정한 결과 가열시간 8 시간 가열하여 추출한 시료구에서 고형분함 량이 $2.30 \%$ 로 가장 높게 나타났으며, 이론수율은 $2.63 \mathrm{~g}$, 엽 산함량은 $55.75 \mu \mathrm{g} / 100 \mathrm{~g}$ 으로 가장 높은 함량을 보였다.

Park등(2017)은 조리법에 따라 엽산가공계수 및 잔존율을 분석하였는데, 느타리버섯을 포함한 모든 버섯이 대부분의 조리에 의하여 엽산 손실이 발생된다고 보고하였다. 이는 조 리가공 중에 엽산이 추출되는 것으로 사료되며, 본 연구는 열
수 및 주정 추출법을 통하여 엽산을 효과적으로 추출하여 엽 산원료로 사용하는 것을 목적으로 하였기 때문에 원료 자체 잔존하는 엽산보다 추출되어 나오는 엽산함량이 중요하였고, 엽산의 최적의 추출법을 찾고자 본 연구를 진행하였으며, 최 적의 엽산추출을 위한 느타리버섯의 최적 추출조건을 설정하 고자 용매량, 가열시간, 가열온도에 변화에 따른 수율 및 엽 산 햠량을 측정한 결과 용매량은 20 배수, 가열온도는 $80^{\circ} \mathrm{C}$, 가열시간은 8시간이 가장 좋은 것으로 판단되었다.

\section{엽산 추출을 위한 최적 에탄올추출조건 설정}

최적의 엽산추출을 위한 느타리버섯 최적 추출조건 설정 을 위해 추출조건을 표준화 하고자 용매로 에탄올을 사용하 고 에탄올 농도, 추출온도. 추출시간 변화에 따라 고형분, 이 론수율, 엽산함량을 측정한 결과는 Table 8-10과 같다.

에탄올을 용매로 이용하여 느타리버섯 최적 추출조건 설 정을 위하여 첫 번째 용매 농도에 따른 느타리버섯의 추출효 율을 확인하였다. 용매농도는 에탄올 $30 \%, 40 \%, 50 \%$ 및 $60 \%$ 농도로 설정을 하고, 용매량은 열수추출에서 최적화된 20 배수의 용매량을 사용하여 추출하였다. 즉, 원물 $1 \mathrm{~kg}$ 에 농

Table 8. Extraction efficiency and folic acid content of oyster mushroom according to ethanol concentration

\begin{tabular}{|c|c|c|c|c|c|c|c|}
\hline \multicolumn{4}{|c|}{ Extraction condition } & \multicolumn{4}{|c|}{ Extraction efficiency } \\
\hline $\begin{array}{c}\text { Concentration } \\
(\%)\end{array}$ & $\begin{array}{l}\text { Solvent } \\
\text { volume } \\
\text { (L) }\end{array}$ & $\begin{array}{l}\text { Extraction } \\
\text { time } \\
\text { (h) }\end{array}$ & $\begin{array}{c}\text { Extraction } \\
\text { temperature } \\
\left({ }^{\circ} \mathrm{C}\right)\end{array}$ & $\begin{array}{l}\text { Final quantity } \\
\text { (L) }\end{array}$ & $\begin{array}{l}\text { Solid content } \\
\left.\text { ( }{ }^{\circ} \text { Brix }\right)\end{array}$ & Yield (g) & $\begin{array}{l}\text { Folic acid content } \\
\quad(\mathrm{ug} / 100 \mathrm{~g})\end{array}$ \\
\hline 30 & 20 & 8 & 50 & 7.8 & $3.26 \pm 0.11^{1) \mathrm{ab} 2)}$ & $2.65 \pm 0.01^{\mathrm{ab}}$ & $41.36 \pm 2.74^{\mathrm{a}}$ \\
\hline 40 & 20 & 8 & 50 & 8.6 & $3.13 \pm 0.05^{\mathrm{c}}$ & $2.59 \pm 0.08^{\mathrm{ab}}$ & $39.44 \pm 0.90^{\mathrm{a}}$ \\
\hline 50 & 20 & 8 & 50 & 8.9 & $3.73 \pm 0.05^{\mathrm{a}}$ & $3.23 \pm 0.05^{\mathrm{a}}$ & $38.86 \pm 0.55^{\mathrm{a}}$ \\
\hline 60 & 20 & 8 & 50 & 8.8 & $3.36 \pm 0.05^{\mathrm{b}}$ & $2.99 \pm 0.02^{\mathrm{b}}$ & $34.56 \pm 0.55^{\mathrm{b}}$ \\
\hline
\end{tabular}

${ }^{1)}$ Each value represents the mean $\pm \mathrm{SD}$ of three determinations.

${ }^{2)}$ Mean with different superscripts $\left({ }^{\mathrm{a}-\mathrm{c}}\right)$ are significantly different at $\mathrm{p}<0.05$ by Duncan's multiple range test. 
Table 9. Extraction efficiency and folic acid content according to extraction temperature with ethanol

\begin{tabular}{|c|c|c|c|c|c|c|c|}
\hline \multicolumn{4}{|c|}{ Extraction condition } & \multicolumn{4}{|c|}{ Extraction solution } \\
\hline $\begin{array}{c}\text { Concentration } \\
(\%)\end{array}$ & $\begin{array}{l}\text { Solvent } \\
\text { volume } \\
\text { (L) }\end{array}$ & $\begin{array}{l}\text { Extraction } \\
\text { time } \\
\text { (h) }\end{array}$ & $\begin{array}{c}\text { Extraction } \\
\text { temperature } \\
\text { (C) }\end{array}$ & $\begin{array}{l}\text { Final quantity } \\
\text { (L) }\end{array}$ & $\begin{array}{l}\text { Solid content } \\
\quad\left({ }^{\circ} \text { Brix }\right)\end{array}$ & Yield (g) & $\begin{array}{l}\text { Folic acid content } \\
\qquad(\mu \mathrm{g} / 100 \mathrm{~g})\end{array}$ \\
\hline 50 & 20 & 8 & 50 & 8.7 & $\left.3.06 \pm 0.05^{1) \mathrm{c} 2}\right)$ & $2.64 \pm 0.03^{d}$ & $40.7 \pm 0.72^{\mathrm{a}}$ \\
\hline 50 & 20 & 8 & 60 & 8.7 & $3.16 \pm 0.05^{\mathrm{bc}}$ & $2.77 \pm 0.01^{\mathrm{c}}$ & $38.70 \pm 0.62^{\mathrm{b}}$ \\
\hline 50 & 20 & 8 & 70 & 8.8 & $3.26 \pm 0.05^{\mathrm{b}}$ & $2.88 \pm 0.07^{\mathrm{b}}$ & $38.26 \pm 0.61^{b}$ \\
\hline 50 & 20 & 8 & 80 & 8.9 & $3.46 \pm 0.05^{\mathrm{a}}$ & $3.13 \pm 0.05^{\mathrm{a}}$ & $38.30 \pm 0.55^{\mathrm{b}}$ \\
\hline
\end{tabular}

${ }^{1)}$ Each value represents the mean $\pm \mathrm{SD}$ of three determinations.

${ }^{2}$ Mean with different superscripts $\left({ }^{\mathrm{a}-\mathrm{d}}\right)$ are significantly different at $\mathrm{p}<0.05$ by Duncan's multiple range test.

Table 10. Extraction efficiency and folic acid content according to extraction time with ethanol

\begin{tabular}{|c|c|c|c|c|c|c|c|}
\hline \multicolumn{4}{|c|}{ Extraction condition } & \multicolumn{4}{|c|}{ Extraction solution } \\
\hline $\begin{array}{c}\text { Concentration } \\
(\%)\end{array}$ & $\begin{array}{l}\text { Solvent } \\
\text { volume } \\
\text { (L) }\end{array}$ & $\begin{array}{c}\text { Extraction } \\
\text { time } \\
\text { (hour) }\end{array}$ & $\begin{array}{c}\text { Extraction } \\
\text { temperature } \\
\text { (C) }\end{array}$ & $\begin{array}{l}\text { Final quantity } \\
\text { (L) }\end{array}$ & $\begin{array}{l}\text { Solid content } \\
\quad\left({ }^{\circ} \text { Brix }\right)\end{array}$ & Yield (g) & $\begin{array}{l}\text { Folic acid content } \\
\qquad(\mu \mathrm{g} / 100 \mathrm{~g})\end{array}$ \\
\hline 50 & 20 & 2 & 50 & 8.8 & $2.06 \pm 0.05^{1)(2)}$ & $1.72 \pm 0.13^{\mathrm{c}}$ & $29.50 \pm 1.10^{\mathrm{d}}$ \\
\hline 50 & 20 & 4 & 50 & 8.7 & $2.36 \pm 0.15^{b}$ & $2.11 \pm 0.06^{b}$ & $33.36 \pm 0.80^{\mathrm{c}}$ \\
\hline 50 & 20 & 6 & 50 & 8.8 & $2.60 \pm 0.20^{\mathrm{b}}$ & $2.47 \pm 0.06^{\mathrm{a}}$ & $37.30 \pm 1.70^{\mathrm{b}}$ \\
\hline 50 & 20 & 8 & 50 & 8.8 & $3.06 \pm 0.05^{\mathrm{a}}$ & $2.59 \pm 0.06^{\mathrm{a}}$ & $41.10 \pm 0.87^{\mathrm{a}}$ \\
\hline
\end{tabular}

${ }^{1)}$ Each value represents the mean $\pm \mathrm{SD}$ of three determinations.

${ }^{2)}$ Mean with different superscripts $\left({ }^{\mathrm{a}-\mathrm{d}}\right)$ are significantly different at $\mathrm{p}<0.05$ by Duncan's multiple range test.

도가 각각 조절된 에탄올 $20 \mathrm{~L}$ 를 첨가하여 $50^{\circ} \mathrm{C}$ 온도조건에 서 8 시간 추출한 결과, 고형분 함량은 에탄올 $50 \%$ 농도에서 8시간 추출한 시료에서 $3.73 \%$ 로 가장 높게 나타났으며, 고형 분 함량도 $3.23 \mathrm{~g}$ 으로 가장 높았다.

에탄올을 이용한 느타리버섯 최적의 추출수율 비교를 위 하여 용매농도를 $50 \%$ 로 고정한 뒤 추출온도를 $50^{\circ} \mathrm{C}, 60^{\circ} \mathrm{C}$, $70^{\circ} \mathrm{C}$ 및 $80^{\circ} \mathrm{C}$ 로 설정하고, 추출효율 및 엽산 햠량 변화를 측 정한 결과 고형분 함량은 가열온도 $80^{\circ} \mathrm{C}$ 로 추출한 시료에서 $3.46 \%$ 로 가장 높았으며, $50{ }^{\circ} \mathrm{C}$ 로 추출한 시료가 $3.06 \%$ 로 가장 낮은 함량을 나타내어 추출온도가 높아질수록 고형분 함량이 증가하는 경향을 나타내었고, 고형분 함량 역시 같은 결과를 보였다. 하지만 엽산함량은 추출온도 $50^{\circ} \mathrm{C}$ 에서 추출한 시료 에서 가장 높게 나타났으며, 다른 시료구는 유의적은 차이를 보이지 않았다.

느타리 에탄올추출물의 고형분과 수율은 추출온도가 높아 짐에 따라 함량이 높아졌으나, 엽산 함량은 큰 차이를 보이지 않았다. 따라서 산업적으로 활용하기 위한 느타리버섯의 엽산 추출의 최적온도는 $50^{\circ} \mathrm{C}$ 가 가장 적합할 것으로 사료된다. 또 한, 추출시간 변화에 따른 느타리버섯 추출효율 및 엽산함량
변화를 측정하기 위하여 에탄올 농도 $50 \%$, 용매량 20 배수, 추 출온도 $50^{\circ} \mathrm{C}$ 로 고정후 추출시간을 2 시간, 4 시간, 6 시간 및 8 시 간 추출하여 가열시간 변화에 따른 고형분과 엽산함량을 측정 한 결과, 가열시간 8 시간 가열하여 추출한 시료구에서 고형분 함량이 $3.06 \%$ 로 가장 높게 나타났으며, 이론수율은 $2.59 \mathrm{~g}$, 엽 산함량은 $41.10 \mu \mathrm{g} / 100 \mathrm{~g}$ 으로 가장 높은 함량을 보였다

최적의 엽산추출을 위한 느타리버섯의 에탄올 추출조건을 설정하고자 용매농도, 용매량, 가열시간, 가열온도에 변화에 따른 수율 및 엽산햠량을 측정한 결과 용매농도는 애탄올 $50 \%$, 용매량은 20 배수, 가열온도는 $50^{\circ} \mathrm{C}$, 가열시간은 8 시간 이 가장 높은 것으로 나타났다.

\section{열수 및 에탄올 추출물의 일반성분}

본 실험에 사용한 느타리버섯의 추출조건별 일반성분 함 량은 Table 11 과 같다. 느타리버섯의 추출물의 열수추출물은 회분 $0.21 \pm 0.02 \%$, 조지방 $0.23 \pm 0.03 \%$, 조단백 $1.23 \pm 0.03 \%$ 로 나타났다. 에탄올 추출물의 경우 회분 $0.23 \pm 0.02 \%$, 조지방 $0.23 \pm 0.03 \%$, 조단백 $1.23 \pm 0.03 \%$ 로 나타나 열수추출물과 에 탄올추출물의 일반성분 차이는 없었다. 


\section{열수 및 에탄올 추출물의 유리당 함량}

느타리버섯의 추출방법에 따른 유리당 함량의 결과는 Table 12와 같다. 추출물별 유리당 함량은 2가지 시료 모두 fructose, glucose, lactose, maltose 4가지 유리당이 검출되었 으며, 2가지 추출물모두 주요 유리당은 fructose와 glucose로 나타났다.

추출물별 유리당 함량을 보면 열수 추출은 glucose 1.388 $\mathrm{mg} \%$, fructose $517 \mathrm{mg} \%$, lactose $209 \mathrm{mg} \%$, maltose 427 $\mathrm{mg} \%$ 로 나타났고 주정추출은 glucose $452 \mathrm{mg} \%$, fructose 148 $\mathrm{mg} \%$, lactose $78.3 \mathrm{mg} \%$, maltose $178 \mathrm{mg} \%$ 로 열수추출한 추 출물이 에탄올추출한 추출물보다 더 높은 함량을 나타내었 다. 이는 $100 \%$ 열수로 추출하였을 때 유리당이 더 많이 용출 되어 나타난 결과로 판단된다.

\section{열수 및 에탄올 추출물의 유기산 함량}

느타리버섯의 추출방법에 따른 유기산 함량의 결과는 Table 13과 같다. Citric acid, acetic acid, succinic acid 및 lactic acid 총 4종이 검출되었으며, citric acid와 lactic acid 의 함량이 모든 시료구에서 높게 나타났다. 추출방법에 따른
유기산 함량은 열수추출물이 citric acid $14.078 \mathrm{mg} \%$, acetic acid $2.26 \mathrm{mg} \%$, succinic acid $9.36 \mathrm{mg} \%$, lactic acid $9.46 \mathrm{mg} \%$ 로 에탄올 추출물과 비슷하거나 높은 결과를 나타내었다.

\section{열수 및 에탄올 추출물의 엽산 함량}

느타리버섯의 추출방법에 따른 엽산분석의 결과는 Table 14 와 같다. 열수추출물의 엽산함량은 $55.46 \mu \mathrm{g} \%$ 로 나타났 으며, 주정추출물의 엽산함량은 $43.03 \mu \mathrm{g} \%$ 로 열수추출물에 서 엽산함량이 높았다. 전체적인 결과를 보면 엽산함량은 에 탄올 추출물보다 열수 추출물에서 더 높은 결과를 나타내었 고, 이는 엽산이 수용성 비타민 B 그룹(Ji 등, 2009; Jin과 $\mathrm{Lim}, 2001)$ 의 하나이기 때문에 물에서 용출이 더 잘 되었을 것으로 판단된다.

\section{요 약}

본 연구에서는 느타리버섯으로부터 엽산을 추출하기 위한 최적의 조건을 수립하고자 열수 및 에탄올을 사용하여 추출 조건을 설정하였고, 느타리버섯으로부터 엽산을 추출하기 위

Table 11. Proximate components of oyster mushroom extracts by extraction methods

\begin{tabular}{cccc}
\hline Extraction method & Ash (\%) & Crude fat (\%) & Crude protein (\%) \\
\hline Hot water extracts & $0.21 \pm 0.02^{1)}$ & $0.23 \pm 0.03$ & $1.23 \pm 0.03$ \\
Ethanol extracts & $0.23 \pm 0.02$ & $0.23 \pm 0.03$ & $1.23 \pm 0.03$ \\
\hline
\end{tabular}

${ }^{1)}$ Each value represents the mean \pm SD of three determinations.

Table 12. Free sugar contents of oyster mushroom extracts by extraction methods

\begin{tabular}{ccccc}
\hline \multirow{2}{*}{ Extraction method } & \multicolumn{4}{c}{ Free suger $(\mathrm{mg} \%)$} \\
\cline { 2 - 5 } & Glucose & Fructose & Lactose & Maltose \\
\hline Hot water extracts & $1,388 \pm 86.55^{1)}$ & $517 \pm 68.06$ & $209 \pm 5.13$ & $427 \pm 17.21$ \\
Ethanol extracts & $452 \pm 27.53$ & $148 \pm 36.11$ & $78.3 \pm 3.05$ & $178 \pm 6.08$ \\
\hline
\end{tabular}

${ }^{1)}$ Each value represents the mean \pm SD of three determinations.

Table 13. Organic acid contents of oyster mushroom extracts by extraction methods

\begin{tabular}{cccccc}
\hline \multirow{2}{*}{ Extraction method } & \multicolumn{5}{c}{ Organic acid $(\mathrm{mg} \%)$} \\
\cline { 2 - 6 } & Citric acid & Malic acid & Acetic acid & Succinic acid & Lactic acid \\
\hline Hot water extracts & $14.07 \pm 0.30^{1)}$ & $\mathrm{ND}^{2)}$ & $2.26 \pm 0.15$ & $9.36 \pm 0.15$ & $9.46 \pm 0.05$ \\
Ethanol extracts & $14.20 \pm 0.75$ & $\mathrm{ND}$ & $2.03 \pm 0.05$ & $8.03 \pm 0.05$ & $9.13 \pm 0.05$ \\
\hline
\end{tabular}

${ }^{1)}$ Each value represents the mean $\pm \mathrm{SD}$ of three determinations.

${ }^{2} \mathrm{ND}$, not detected. 
Table 14. Folic acid content of oyster mushroom extracts by extraction methods

\begin{tabular}{cc}
\hline Extraction method & Folic acid content $(\mu \mathrm{g} / 100 \mathrm{~g})$ \\
\hline Hot water extracts & $55.46 \pm 0.83^{1)}$ \\
Ethanol extracts & $42.03 \pm 0.40$ \\
\hline
\end{tabular}

${ }^{1)}$ Each value represents the mean $\pm \mathrm{SD}$ of three determinations.

한 기초자료로 삼고자 본 연구를 수행하였다. 느타리버섯의 건조방법에 따른 일반성분은 차이가 없었지만 엽산함량은 동 결건조 $55.10 \mu \mathrm{g} \%$, 냉풍건조 $54.56 \mu \mathrm{g} \%$, 열풍건조는 53.83 $\mu \mathrm{g} / 100 \mathrm{~g}$ 으로 열품건조가 약간 높았다. 느타리버섯의 주요 유리당은 fructose와 glucose 유기산은 citric acid와 lactic acid 로 나타났다. 최적의 엽산 추출을 위하여 느타리버섯 최적 추 출조건을 설정하고자 용매종류, 용매량, 가열시간, 가열온도 에 변화에 따른 수율 및 엽산햠량을 측정하였다. 그 결과, 열 수 추출은 고형분 대비 20 배수, 가열온도 $80^{\circ} \mathrm{C}$, 가열시간 8 시 간이 엽산추출에 효과적이었으며, 에탄올 추출은 에탄올 농 도 $50 \%$, 고형분 대비 용매량 20 배수, 가열온도는 $50^{\circ} \mathrm{C}$, 가열 시간은 8 시간이 가장 효과적인 것으로 판단되었다. 추출조건 에 따른 일반성분의 차이는 없었고 유리당 함량은 열수 추출 이 높았으며, 유기산 함량은 차이기 없었다. 엽산함량은 열수 추출물에서 더 높은 결과를 나타내었고, 이는 엽산이 수용성 물질이기 때문에 에탄올보다 열수에서 추출효율이 높은 것으 로 판단된다.

\section{감사의 글}

이 연구는 2020년도 광주대학교 대학 연구비의 지원을 받 아 수행되었음.

\section{Conflict of interests}

The authors declare no potential conflict of interest.

\section{ORCID}

Ki-Man Kim https://orcid.org/0000-0002-2325-077X

\section{References}

AOAC. Official Methods of Analysis. 16th ed, Association of Official Analytical Chemists, Arlington, VA, USA p 69-74 (1995)
Arcot J, Shrestha A. Folate: Methods of analysis. Trends Food Sci Technol, 16, 253-266 (2005)

Ball GFM. Water-Soluble Vitamin Assays in Human Nutrition. Springer Berlin, Germauy, p 59-63 (2012)

Barros L, Baptista P, Correia DM, Casal S, Oliveira B, Ferreira ICFR. Fatty acid and sugar compositions, and nutritional value of five wild edible mushrooms from Northeast Portugal. Food Chem, 105, 140-145 (2007)

Blom HJ, Smulders Y. Overview of homocysteine and folate metabolism. With special references to cardiovascular disease and neural tube defects. J Inherit Metab Dis, 34, 75-81 (2011)

Chang N, Kang M, Paik HY, Kim IH, Cho YW, Park SC, Shin YW. Serum folate and iron levels of pregnant, lactating, and non-pregnant, non-lactating women. Korean J Nutr, 26, 67-75 (1993)

DeVries JW, Rader JI, Keagy PM, Hudson CA, Angyal G, Arcot J, Castelli M, Doreanu N, Hudson C, Lawrence P, Martin J, Peace R, Rosner L, Strandler HS, Szpylka J, van den Berg H, Wo C, Wurz C. Microbiological assaytrienzyme procedure for total folates in cereals and ce real foods: collaborative study. J AOAC Int, 88, 5-15 (2005)

Green R. Indicators for assessing folate and vitamin B-12 status and for monitoring the efficacy of intervention strategies. Am J Clin Nutr, 94, 666S-672S (2011)

Gropper SS, Smith JL, Groff JL. Advanced Nutrition and Human Metabolism. 4th ed, Thomson Wadsworth, Belmont, CA, USA, p 301-315 (2005)

Hong JS, Kim YH, Lee KR, Kim MK, Cho CI, Park KH, Choi, YH, Lee JB. Composition of organic acid and fatty acid in Pleurotus ostreatus, Lentinus edodes and Agaricus bisporus. Korean J Food Sci Technol, 20, 100-105 (1988)

Hossain S, Hashimoto M, Choudhury EK, Alam N, Hussain S, Hasan M, Choudhury SK, Mahmud I. Dietary mushroom (Pleurotus ostreatus) ameliorates atherogenic lipid in hypercholesterolaemic rats. Clin Exp Pharmacol Physiol, 30, 470-475 (2003)

Je HJ, Kim HY, Ha GJ, Ha IJ, Cho SR. Quality characteristics of Pleurotus eryngii, Lentinus edodes GNA01 and Grifola frondosa as affected by different drying methods. Korean J Food Preserv, 25, 181-188 (2018)

Ji HJ, Kim S, Yon M, Hyun T. Folate content of fast foods and processed foods. Korean J Nutr, 42, 397-405 (2009) 
Jin HO, Lim HS. Major foods for folate and their folate contents of Korean child-bearing women. J Korean Soc Food Sci Nutr, 30, 152-158 (2001)

Jing H, Kitts DD. Antioxidant activity of sugar-lysine Maillard reaction products in cell free and cell culture systems. Arch Biochem Biophys, 429, 154-163 (2004)

Jo EK. Physiological and antioxidant activities of subcritical water extracts from gold oyster mushroom (Pleurotus cornucopiae var. citrinopileatus). MS Thesis. Kyungnam University, Korea, p 38-39 (2012)

Jung IC, Park S, Park KS, Ha HC, Kim SH, Kwon YI, Lee JS. Antioxidative effect of fruit body and mycelial extracts of Pleurotus ostreatus. Korean J Food Sci Technol, 28, 464-469 (1996)

Kang M, Chang N. Effect of dietary folate intakes on serum folate levels of pregnant and lactating women. Korean J Nutr, 26, 433-442 (1993)

Kim HJ, Bae JT, Lee JW, Hwang Bo MH, Im HG, Lee IS. Antioxidant activity and inhibitive effects on human leukemia cells of edible mushrooms extracts. Korean J Food Preserv, 12, 80-85 (2005)

Kim HK, Lee BY, Shin DB, Kwon JH. Effects of roasting conditions on physicochemical characteristics and volatile flavor components of chicory rots. Korean J Fod Sci Technol, 30, 1279-1284 (1998)

Kim HS, Ha HC, Kim TS. Research and prospects in new functional mushrooms: Tremella fuciformis, Grofora frondosa, and Hypsizigus marmoreus. Food Sci Ind, 36, 42-46 (2003)

Kim JI, Kang MJ. Recent consumption and physiological status of vitamin D in Korean population. Korean
Industry and Nutrition, 17, 7-10 (2012)

Kim JY, Moon GD, Lee SD, Cho SH, Kang HI, Yee ST, Seo KI. Physicochemical properties of Pleurotus eryngii. Korean J Food Preserv, 11, 347-351 (2004)

Kim MS, Kim GH. Contents of nucleic acids (nucleosides and mono-nucleotides) in extracts of Pleurotus ostreatus, Agaricus bisporus and Flammulina velutipes. Korean J Food Nutr 23, 376-380 (2010)

Lee KM, Sim U, Choi YM, Lee JS. Nutritional compositions and antioxidant activities of frequently consumed mushrooms in Korea. J Korean Soc food Sci Nutr, 47, 1178-1184 (2018)

Min HS. Changes of folate content in spinach by cooking and storage: the comparisons of thermal destruction and loss of folate into cooking water by blanching time of spinach. J Korean Soc Food Sci Nutr, 27, 286-290 (1998)

Park HA, Kim SY. Recent advance on vitamin D. J Korean Med Assoc, 56, 310-318 (2013)

Park MH, Oh KY, Lee BW. Anti-cancer Activity of Lentinus edoeds and Pleurotus astreatus Korean J Food Sci Technol, 30, 702-708 (1998)

Park SJ, Park SH, Chung HJ, Lee JS, Hyun TS, Chun JY. Effects of different cooking methods on folate retention in selected mushrooms. Korean J Food Preserv, 24, 1103-1112 (2017)

Qi Y, Zhao X, Lim YI, Park KY. Antioxidant and anticancer effects of edible and medicinal mushrooms. J Korean Soc Food Sci Nutr, 42, 655-662 (2013)

Yang HC, Song CH, Kweon MH. Mycelial New Material, Food Functional Technology. Hanlimwon, Seoul, Korea, p 187-189 (1996) 